\title{
Study of Depression and Anxiety in Endoscopically Diagnosed Cases of Gastro- Oesophageal Reflux Disease (GERD)
}

\author{
Pawan Rathi ${ }^{1}$, Amandeep Gill2 ${ }^{2}$ Ganpat K Vankar ${ }^{3}$, Nishant Ohri ${ }^{4}$, Aditi Patel ${ }^{5}$ \\ ${ }^{1}$ Associate Professor \\ ${ }^{2,4}$ Senior Resident \\ ${ }^{3}$ Professor and Head of Department \\ ${ }^{5}$ Junior Resident \\ Department of Psychiatry, Sri Aurobindo Medical College and P.G. Institute, Indore \\ Corresponding author: Dr. Pawan Rathi \\ Email-drpawanrathi@yahoo.co.in
}

\begin{abstract}
Background and Objectives: To study the Depression and Anxiety in diagnosed esophageal reflux disease cases and to compare it with the age and sex matched controls

Methods: Study conducted in the gastro-enterology unit of Sri Aurobindo Medical College and PostGraduate Institute, Indore. After taking an informed consent in their local language (Hindi), we recruited 100 patients with symptoms and endoscopic evidence of GERD along with 100 age and sex matched controls. Patients diagnosed to have GERD on the basis of either frequent complaints of heartburn and/or acid regurgitation for the last 3 months and the presence of endoscopic evidence of GERD. Following instruments were administered: A semi-structured socio-demographic pro-forma, Mini International Neuropsychiatric interview, Hamilton Rating Scale for Depression, Hamilton Rating Scale for Anxiety and Diagnostic and Statistical Manual of Mental Disorders - 5.

Results: The present study revealed that significantly higher number of GERD patients suffered from depression (46\%) and anxiety (31\%) as compared to their matched controls. Also, both HAM-D and HAMA scores showed higher numbers of GERD patients to be having 'severe' or 'very severe' forms of psychological morbidity than the controls. Patients with GERD used tobacco, in smoking or chewing form, in significantly higher numbers than the controls, while alcohol users were underrepresented in both groups. Conclusion: In summary, among the 100 GERD cases 56 were found to have psychiatric morbidity in form of either anxiety or depression.
\end{abstract}

Keywords: GERD, Depression, Anxiety,

(Paper received $-29^{\text {th }}$ March 2018, Peer review completed $-30^{\text {th }}$ April 2018)

(Accepted $-4^{\text {th }}$ May 2018)

\section{INTRODUCTION}

GERD is characterised by complex relationship between acid production and symptoms, where stomach content flowing back through lower oesophagus sphincter causes heartburn, subjective feeling of regurgitation and other complications [1-2]. GERD is frequently seen in Gastroenterology out patients across the world with prevalence estimates of $18.1 \%-27.8 \%$ in North America, 8.8\% - 25.9\% in Europe, 2.5\% $7.8 \%$ in East Asia, $8.7 \%-33.1 \%$ in the Middle East, $11.6 \%$ in Australia and $23.0 \%$ in South America. Researchers showed prevalence of GERD in an urban adult population from northern India is $16.2 \%$ which 
is similar to other industrialized countries. Higher body mass index, current smoking, and presence of asthma or hypertension predisposes to GERD in our population [3].

A prospective, multi-centric study involving 3224 subjects regarding the frequency, severity and duration of heartburn, regurgitation and other symptoms of GERD by the Indian Society of Gastroenterology showed $7.6 \%$ of Indian subjects had significant GERD symptoms. Consumption of non-vegetarian foods was an independent predictor of GERD. Patient seeking treatments for GERD in Gastroenterology OPD are often referred to psychiatrists for problems like mood, anxiety and sleep disturbances. GERD and mental wellbeing have been examined in both gastrointestinal and psychiatric-based clinical care settings with reports of increased likelihood of GERD amongst depressed individuals and vice-versa [4-5] and increased risk of anxiety [6], neuroticism in temperament [7] and general psychological distress amongst GERD sufferers [8]. We are well aware of psychosomatics, which is based on the belief that psychic stimuli can produce a response in somatic structures via direct and indirect means. While there is an extensive evidence base suggesting an association between irritable bowel syndrome and psychiatric disorders [9], relationship between GERD and psychological disorders although has been recognized in the literature, but there are very few studies that attempt to define the exact relationship between the two abnormalities and the proper management of GERD patients with psychological co morbidity.

\section{METHODOLOGY}

The study was initiated after the approval of the institutional ethics committee. Data was collected over a period of 18 months with the co-operation and assistance of the department of the gastro-enterology unit of Sri Aurobindo Medical College and Post-Graduate Institute, Indore. During this time 100 cases with symptoms and endoscopic evidence of GERD along with 100 age and sex matched controls were studied. Non consenting individuals were excluded. The subjects for the study was selected from the clinically diagnosed patients of Gastro-esophageal reflux disease and their caregivers

Patients diagnosed to have GERD Subjects fulfilling the inclusion criteria were identified. They were informed in detail regarding the study and written informed consent was taken in their local language. Sociodemographic data and clinical information were collected on a semi-structured pro-forma.

\section{Inclusion Criteria}

- Patients of either gender

- Aged 16 to 70 years.

- Patients diagnosed with GERD

\section{Exclusion Criteria}

- H/o mental retardation, any major psychotic illness, any chronic medical illness (other than acid peptic disease).

- Patients with complications of GERD like oesophageal stricture, Barrett's oesophagus and adenocarcinoma.

- Patients who refused to give informed consent.

\section{RESULTS}

\section{Demographic Characteristics}

The study was conducted over six months and included 100 adult patients and 100 controls. The study group consisted of total of 100 cases of GERD and their 100 age and sex matched controls (relatives and attendants) visiting the Gastroenterology OPD. Out of 100 cases 38 were male, comprising and the rest 62 were female. Among the control 34 were males and 66 females. The age of subjects enrolled in study range between 16 to 70 years. In both cases and control the highest numbers were in the bracket 30 to 39 years (33\% cases and $31 \%$ control). Mean age among cases was 37.47 and among controls was 35.76. 
Table 1: Socio-demographic Characteristics of the study population

\begin{tabular}{|c|c|c|c|}
\hline & $\begin{array}{l}\text { Case } \\
N=100\end{array}$ & $\begin{array}{l}\text { Control } \\
\mathrm{N}=100\end{array}$ & Statistics \\
\hline $\begin{array}{l}\text { Age } \\
16-29 \\
30-39 \\
40-49 \\
50-69 \\
>70\end{array}$ & $\begin{array}{l}28 \\
33 \\
19 \\
20 \\
0\end{array}$ & $\begin{array}{l}34 \\
31 \\
23 \\
11 \\
1\end{array}$ & $\begin{array}{l}X^{2}=4.637 \\
d f=4 \\
p=0.32\end{array}$ \\
\hline $\begin{array}{l}\text { Sex } \\
\text { Male } \\
\text { Female }\end{array}$ & $\begin{array}{l}38 \\
62\end{array}$ & $\begin{array}{l}34 \\
66\end{array}$ & $\begin{array}{l}X^{2}=0.3472 \\
d f=1 \\
p=0.55\end{array}$ \\
\hline $\begin{array}{l}\text { Education } \\
\text { Illiterate } \\
\text { Primary } \\
\text { Secondary } \\
\text { Higher secondary } \\
\text { Graduation } \\
\text { Post-graduation }\end{array}$ & $\begin{array}{l}22 \\
18 \\
17 \\
21 \\
19 \\
3\end{array}$ & $\begin{array}{l}9 \\
16 \\
20 \\
21 \\
30 \\
4\end{array}$ & $\begin{array}{l}X^{2}=8.425 \\
d f=5 \\
p=0.13\end{array}$ \\
\hline $\begin{array}{l}\text { Residence } \\
\text { Rural } \\
\text { Urban }\end{array}$ & $\begin{array}{l}48 \\
52\end{array}$ & $\begin{array}{l}52 \\
48\end{array}$ & $\begin{array}{l}X^{2}=0.32 \\
d f=1 \\
p=0.57\end{array}$ \\
\hline $\begin{array}{l}\text { Religion } \\
\text { Hindu } \\
\text { Muslim }\end{array}$ & $\begin{array}{l}94 \\
6\end{array}$ & $\begin{array}{l}95 \\
5\end{array}$ & $\begin{array}{l}X^{2}=0.096 \\
d f=1 \\
p=0.75\end{array}$ \\
\hline $\begin{array}{l}\text { Marital status } \\
\text { Married } \\
\text { Unmarried }\end{array}$ & $\begin{array}{l}91 \\
9\end{array}$ & $\begin{array}{l}82 \\
18\end{array}$ & $\begin{array}{l}X^{2}=3.46 \\
d f=1 \\
p=0.06\end{array}$ \\
\hline $\begin{array}{l}\text { Occupation } \\
\text { Housewife } \\
\text { Farmer } \\
\text { Professional } \\
\text { Skilled worker } \\
\text { Semi-skilled job } \\
\text { Unskilled worker } \\
\text { Student } \\
\text { Unemployed/ retired }\end{array}$ & $\begin{array}{l}29 \\
24 \\
6 \\
7 \\
16 \\
5 \\
8 \\
5\end{array}$ & $\begin{array}{l}24 \\
26 \\
8 \\
8 \\
18 \\
4 \\
8 \\
4\end{array}$ & $\begin{array}{l}X 2=1.244 \\
d f=7 \\
p=0.98\end{array}$ \\
\hline
\end{tabular}

A higher number of subjects were married ( $91 \%$ of the cases and $82 \%$ of the controls). The subjects were comparable on the basis of age and marital status in both the groups. The p-values were above 0.05 and therefore not significant. Most of the patients $(n=94)$ interviewed were Hindu and the rest were Muslim. $18 \%$ had received primary education, $60 \%$ had received education up to the secondary level or higher, while 22 percent were illiterate. Majority of the subjects were farmers (24\%) while 29 percent were housewives, $16 \%$ were semi-skilled workers. Among the rest $7 \%$ percent worked as skilled workers, and unskilled worker category, $6 \%$ were professionals and $5 \%$ were either retired or unemployed. 
Table 2: Alcohol Use, Tobacco Use, BMI and Spicy Food: Relation with GERD

\begin{tabular}{|c|c|c|c|}
\hline & Case & Control & \\
\hline $\begin{array}{l}\text { Alcohol } \\
\text { Yes } \\
\text { No }\end{array}$ & $\begin{array}{l}9 \\
91\end{array}$ & $\begin{array}{l}11 \\
89\end{array}$ & $\begin{array}{l}X^{2}=0.22 \\
d f=1 \\
p=0.6374\end{array}$ \\
\hline $\begin{array}{l}\text { Tobacco } \\
\text { Yes } \\
\text { No }\end{array}$ & $\begin{array}{l}69 \\
31\end{array}$ & $\begin{array}{l}26 \\
74\end{array}$ & $\begin{array}{l}X^{2}=37 \\
d f=1 \\
p<0.0000001\end{array}$ \\
\hline $\begin{array}{ll}\text { BMI } & \\
>18.5 & \text { (Underweight) } \\
18.5-24.9 & \text { (Healthy) } \\
25-29.9 & \text { (Overweight) } \\
>30 & \text { (Obese) }\end{array}$ & $\begin{array}{l}29 \\
57 \\
9 \\
5\end{array}$ & $\begin{array}{l}16 \\
74 \\
10 \\
0\end{array}$ & $\begin{array}{l}X^{2}=11.01 \\
d f=3 \\
p<0.01165\end{array}$ \\
\hline $\begin{array}{l}\text { Spicy/Non Spicy Food } \\
\text { Spicy } \\
\text { Non-Spicy }\end{array}$ & $\begin{array}{l}63 \\
36\end{array}$ & $\begin{array}{l}49 \\
51\end{array}$ & $\begin{array}{l}X^{2}=4.33 \\
d f=1 \\
p=0.03266\end{array}$ \\
\hline
\end{tabular}

\section{Substance use}

91 patients and 89 controls were not using alcohol regularly with 9 patients and 11 controls were using it on daily bases. Tobacco was used by 69 patients and only 26 controls. On applying Chi square test. $p$ value was noted to be significant $(\mathrm{p}$ value $=<0.0000001)$

\section{Body Mass Index}

74 controls and 57 patients were healthy (BMI 18.5- 24.9) and 5 cases were obese as compared to none among controls. Difference between BMI valve between cases and control was significant ( $p$ value 0.01165 ). Food preference did not seem to affect GERD.

Table 3: Prevalence of psychiatric morbidity in Patients of GERD

\begin{tabular}{|c|c|c|c|}
\hline & Cases & Control & \\
\hline $\begin{array}{l}\text { MINI-D } \\
\text { Negative } \\
\text { Positive }\end{array}$ & $\begin{array}{l}54 \\
46\end{array}$ & $\begin{array}{l}81 \\
19\end{array}$ & $\begin{array}{l}X^{2}=16.62 \\
d f=1 \\
p=0.00004\end{array}$ \\
\hline $\begin{array}{l}\text { MINI-A } \\
\text { Negative } \\
\text { Positive }\end{array}$ & $\begin{array}{l}69 \\
31\end{array}$ & $\begin{array}{l}89 \\
11\end{array}$ & $\begin{array}{l}X^{2}=12.06 \\
d f=1 \\
p=0.0005\end{array}$ \\
\hline
\end{tabular}

Forty-six patients with GERD were diagnosed as having major depressive disorder and 31 had anxiety Disorder. In the control group, 19 patients had depression and 11 had anxiety disorder. The difference between the patient group and the control was statistically highly significant, $p=0.00004$ for major depressive disorder, and $\mathrm{p}=0.0005$ for anxiety disorder. 
Table 4: Severity of Depression in Patients of GERD

\begin{tabular}{|ll|l|l|l|}
\hline & Case & Control & \\
\hline $\boldsymbol{H} A \boldsymbol{M}-\boldsymbol{D}$ & & & \\
$8-13 \quad$ Mild & 4 & 0 & $\mathrm{X}^{2}=1.8$ \\
$14-18 \quad$ Moderate & 15 & 6 & $\mathrm{df}=3$ \\
$19-22$ & Severe & 12 & 6 & $\mathrm{p}=0.5989$ \\
$>22$ & Very Severe & 15 & 7 & \\
\hline
\end{tabular}

For measuring the severity of major depressive disorder, the Hamilton Depression Rating Scale (HDRS), abbreviated HAM-D was used. The questionnaire is designed for adults and is used to rate the severity of their depression by probing mood, feelings of guilt, suicide ideation, insomnia, agitation or retardation, anxiety, weight loss, and somatic symptoms. Out of a total of 100 patients, 46 were diagnosed of having depression. Four had 'mild' depression (i.e. scores 8-13), 15 had 'moderate' (scores 14-18), 12 had severe (scores 19-22) and 15 had very severe (score > 22). Among the controls, $19 \%$ had depression most of whom had moderate to severe depression.

Table 5: Severity of Anxiety in Patients with GERD

\begin{tabular}{|l|l|l|l|}
\hline & Cases & Control & \\
\hline $\boldsymbol{H} \boldsymbol{A} \boldsymbol{M}-\boldsymbol{A}$ & & & \\
$<14 \quad$ Normal & 2 & 0 & $\mathrm{X}^{2}=3.2$ \\
$14-17$ Mild & 3 & 0 & $\mathrm{df}=3$ \\
$18-24$ Moderate & 14 & 8 & $\mathrm{p}=0.3547$ \\
$25-30$ Severe & 12 & 3 & \\
\hline
\end{tabular}

Out of a total of 100 patients 31 who were positive for Anxiety, only 3 had 'mild Anxiety (i.e. scores 14-17), 14 had moderate Anxiety symptoms (scores 18 -24). 12 patients had severe Anxiety symptoms (score 2530).

\section{Demographic Characteristics in Psychiatric Morbidity in GERD}

When cases of GERD with psychiatric morbidity were compared with GERD patients without psychiatric morbidity following demographic and other characteristics were similar: age, marital status, gender, education level, occupation, religion, place of living, consumption of alcohol or tobacco. No statistically significant difference was observed in both the groups.

\section{DISCUSSION}

\section{Socio-demographic characteristics}

The demographic characteristics of the patient and the control groups were not found to be significantly different on the lines of education, residence, religion, marital status and occupation but numerically very high number of subjects were married in both case and control populations. This can be explained by underrepresentation of unmarried subjects in both groups. Since, the mean ages of the cases and controls were 37.47 and 35.76 years, culturally considered beyond the age of marriage - majority of the subjects could be expected to be married. Overall the demographic characteristics were well matched and comparable, which also reflects in the fact that mostly family members, friends or neighbors of the patients, who did not have gastroenterology related symptoms were taken as controls. 
Table 6: Comparison of demographical characteristics in GERD Patients and Controls.

\begin{tabular}{|c|c|c|c|c|c|}
\hline Variable & $\begin{array}{l}\text { Psychiatric } \\
\text { morbidity } \\
\text { Present }(N=56)\end{array}$ & $\%$ & $\begin{array}{l}\text { Psychiatric } \\
\text { morbidity } \\
\text { Absent }(\mathrm{N}=56)\end{array}$ & $\%$ & Statistics \\
\hline $\begin{array}{l}\text { Age } \\
\text { Range } \\
\text { Mean } \\
\text { (SD) }\end{array}$ & $\begin{array}{l}18-66 \\
30.03 \\
(11.18)\end{array}$ & & $\begin{array}{l}14-70 \\
39.29 \\
(14.11)\end{array}$ & & $\begin{array}{l}X^{2}=3.561 \\
d f=4 \\
p=0.468\end{array}$ \\
\hline $\begin{array}{l}\text { Sex } \\
\text { Male } \\
\text { Female }\end{array}$ & $\begin{array}{l}23 \\
33\end{array}$ & $\begin{array}{l}41.1 \\
58.9\end{array}$ & $\begin{array}{l}15 \\
29\end{array}$ & $\begin{array}{l}34.1 \\
65.9\end{array}$ & $\begin{array}{l}X^{2}=0.501 \\
d f=1 \\
p=0.47\end{array}$ \\
\hline $\begin{array}{l}\text { Marital Status } \\
\text { Married } \\
\text { Unmarried }\end{array}$ & $\begin{array}{l}52 \\
4\end{array}$ & $\begin{array}{l}92.9 \\
7.15\end{array}$ & $\begin{array}{l}40 \\
4\end{array}$ & $\begin{array}{l}90.9 \\
9.1\end{array}$ & $\begin{array}{l}X^{2}=.127 \\
d f=1 \\
p=0.72\end{array}$ \\
\hline $\begin{array}{l}\text { Education } \\
\text { Illiterate } \\
\text { Primary } \\
\text { Secondary } \\
\text { Higher Secondary } \\
\text { Graduation } \\
\text { Post-Graduation }\end{array}$ & $\begin{array}{l}13 \\
9 \\
9 \\
13 \\
11 \\
1\end{array}$ & $\begin{array}{l}23.2 \\
16.4 \\
16.4 \\
23.4 \\
19.6 \\
1.8\end{array}$ & $\begin{array}{l}9 \\
9 \\
8 \\
8 \\
8 \\
2\end{array}$ & $\begin{array}{l}20.5 \\
20.5 \\
18.2 \\
18.2 \\
18.2 \\
4.5\end{array}$ & $\begin{array}{l}X^{2}=1.36 \\
d f=5 \\
p=0.928\end{array}$ \\
\hline $\begin{array}{l}\text { Residence } \\
\text { Rural } \\
\text { Urban }\end{array}$ & $\begin{array}{l}27 \\
29\end{array}$ & $\begin{array}{l}48.2 \\
51.8\end{array}$ & $\begin{array}{l}21 \\
33\end{array}$ & $\begin{array}{l}47.7 \\
52.2\end{array}$ & $\begin{array}{l}X^{2}=0.002 \\
d f=1 \\
p=0.96\end{array}$ \\
\hline $\begin{array}{l}\text { Religion } \\
\text { Hindu } \\
\text { Muslim }\end{array}$ & $\begin{array}{l}54 \\
2\end{array}$ & $\begin{array}{l}96.4 \\
3.6\end{array}$ & $\begin{array}{l}40 \\
4\end{array}$ & $\begin{array}{l}40.9 \\
9.1\end{array}$ & $\begin{array}{l}X^{2}=1.331 \\
d f=1 \\
p=0.24\end{array}$ \\
\hline $\begin{array}{l}\text { Occupation } \\
\text { House wife } \\
\text { Farmer } \\
\text { Professional } \\
\text { Skilled worker } \\
\text { Semi- skilled } \\
\text { Unskilled worker } \\
\text { Student } \\
\text { Unemployed/ retired }\end{array}$ & $\begin{array}{l}16 \\
13 \\
3 \\
1 \\
9 \\
5 \\
5 \\
4\end{array}$ & $\begin{array}{l}28.5 \\
23.2 \\
5.3 \\
1.7 \\
16.0 \\
8.9 \\
8.9 \\
7.1\end{array}$ & $\begin{array}{l}13 \\
11 \\
3 \\
3 \\
9 \\
1 \\
3 \\
1\end{array}$ & $\begin{array}{l}29.5 \\
25 \\
6.8 \\
6.8 \\
20.4 \\
2.3 \\
6.8 \\
2.3\end{array}$ & $\begin{array}{l}X^{2}=5.077 \\
d f=7 \\
p=0.65\end{array}$ \\
\hline $\begin{array}{l}\text { Alcohol } \\
\text { Yes } \\
\text { No }\end{array}$ & $\begin{array}{l}49 \\
7\end{array}$ & $\begin{array}{l}87.5 \\
12.5\end{array}$ & $\begin{array}{l}42 \\
2\end{array}$ & $\begin{array}{l}95.5 \\
4.5\end{array}$ & $\begin{array}{l}X^{2}=1.904 \\
d f=1 \\
p=0.16\end{array}$ \\
\hline $\begin{array}{l}\text { Tobacco } \\
\text { Yes } \\
\text { No }\end{array}$ & $\begin{array}{l}38 \\
18\end{array}$ & $\begin{array}{l}67.9 \\
32.4\end{array}$ & $\begin{array}{l}31 \\
13\end{array}$ & $\begin{array}{l}70.5 \\
29.5\end{array}$ & $\begin{array}{l}X^{2}=0.07 \\
d f=1 \\
\text { p } 0.78\end{array}$ \\
\hline
\end{tabular}

GERD and Alcohol Use

A large majority of subjects in this study (both cases and controls) denied alcohol use. Only $9 \%$ of cases and $11 \%$ of controls had either regular or occasional alcohol use. The difference was not significant. It can also be argued that the number of alcohol drinkers were under-represented in both groups. Many studies 
regarding amount of alcohol use and types of GERD (erosive, non-erosive, symptomatic and asymptomatic) have revealed contradictory results. Researchers in Taiwan conducted a prospective study over 5 months in which 778 subjects underwent esophago-gastro-duodenoscopic examinations. The study concluded that erosive esophagitis was directly related to alcohol consumption [10].

A study involving 205 patients with GERD and 200 controls [11] compared the risk factors and clinical responses to proton pump inhibitors in patients with erosive oesophagitis and non-erosive reflux disease. They found that patients suffering from erosive type of oesophagitis are at higher odds of being regular alcohol users than patients suffering from non-erosive oesophagitis (OR=2.9, 95\% CI: 1.0-8.3) [19]. Though there are fewer studies that have quantified the amount of alcohol intake and compared it with GERD symptoms, one large study from Japan stands out. They studied the relationship between quantity of alcohol consumption and the severity of oesophagitis in $463 \mathrm{men}$, the odds ratios/grams (alcohol)/day of dose response trends for erosive oesophagitis and Barrett's epithelium were 1.015 (95\% CI: 1.004-1.026, p = $0.0066)$ and 1.012 (95\% CI: 1.003-1.021, p = 0.0079), respectively. Alcohol consumption is also associated with an increased risk of erosive oesophagitis and Barrett's epithelium in Japanese men [12].

\section{GERD and Tobacco use}

Sixty nine percent of cases, in contrast to $26 \%$ of controls, agreed that they consumed tobacco in some form or the other. This difference was highly significant $(\mathrm{p}<0.0000001)$ which is in agreement with multiple studies. Smoking seems to be associated with a spectrum of gastroesophageal diseases ranging from erosive gastritis and Barrett's esophagus to esophageal adenocarcinoma [11].

A longitudinal cohort study with nested case-control analysis was performed using data from the GPRD (General Practice Research Database) in the UK. The study included 7451 subjects and found that there were significantly more ex-smokers (OR 1.2 (95\% CI 1.1-1.4)) and slightly more current smokers (OR 1.1 (95\% CI 1.0-1.2) in patients with a new diagnosis of GORD than in the control cohort [13]. Studies measuring physiological parameters such as lower esophageal $\mathrm{pH}$ and cardiac sphincter tone have suggested biologically plausible evidences that smoking indeed has an effect sphincter tone and acid reflux [14]. Kharilas and Gupta [15] evaluated the esophageal sphincter function of chronic smokers compared with non-smokers and to ascertain the acute effects of smoking on the sphincter and the occurrence of acid reflux. As a group, the cigarette smokers had significantly lower oesophageal sphincter pressure compared with non-smokers but the sphincter was not further compromised by acutely smoking cigarettes. Cigarette smoking did, however, acutely increase the rate at which acid reflux events occurred [16].

\section{GERD, Smoking and Depression}

The current study found no significant difference in tobacco use among the patients of GERD with regard to presence or absence of psychiatric morbidity. A study from Taiwan that included 23,698 subjects who were investigated for GERD and also assessed for psychosocial stress and depression using Brief Encounter Psychosocial Instrument and Beck's Depression Inventory, reported that subjects with depression had a higher incidence of current smoking $(29.3 \%$ in depression group vs. $24.8 \%$ in reference group; $p<0.01)$ [24]. Subjects in depression group were also younger and had female predominance, which again was not the case in our study [17].

\section{GERD and Obesity}

A higher percentage of cases (29\%) were underweight according to their BMIs than the controls (16\%), but none of the controls were obese (as opposed to $5 \%$ among the cases). Fifty seven percent of cases and $74 \%$ of controls fell under the 'healthy' category. The difference is significant but this is not enough establish the trend or direction of association of body weight and GERD in this study.

More detailed studies concerning the association of BMI and GERD have shown significant association. Singh and others undertook a prospective study that included 332 adult subjects with gerd in a weight reduction intervention. majority of the subjects (97\%) lost weight (average weight loss: $13 \pm 7.7 \mathrm{~kg}$ ) and as compared with baseline, there was a significant decrease in the overall prevalence of GERD. Overall, $81 \%$ of the subjects had reduction in GERD symptom scores; $65 \%$ had complete resolution and $15 \%$ had partial resolution of reflux symptoms [18]. 
El-Serag and others [19] in their study of 453 volunteers had found a linear relationship between frequency of heartburn and higher BMI. Obese participants were 2.5 times as likely as those with normal BMI $(<25)$ to have reflux symptoms or esophageal erosions. The association between BMI and GERD symptoms persisted in this direction and magnitude after adjustment for potential confounders [19].

\section{GERD: Body weight dissatisfaction and Depression}

More than body mass index, body weight dissatisfaction may lead to depression independent of GERD. Richard and researchers [20] analysed the data of 15,975 Swiss individuals from 2012 Swiss Health Survey. BMI was calculated using the self reported data on height and weight and PHQ-9 (Patient Health Questionnaire) was used to ascertain depression. The stratification by age groups showed significant associations of BWD with depression in young, middle-aged and old individuals in dependent of BMI. Stratification by BMI categories resulted in statistically significant positive associations of body weight dissatisfaction and depression in underweight, normal weight, overweight and obese individuals [21]. Unfortunately, in the present study specific questions regarding weight satisfaction, GERD and depression were not explored, but WHOQoL-BREF included domain questions regarding body image (domain-2), the responses to which showed significantly higher scores among the controls compared to GERD patients $(\mathrm{t}=$ $3.44, \mathrm{df}=198 ; \mathrm{p}=0.0007)$.

\section{Prevalence of Depression and Anxiety in GERD}

Mini international neuropsychiatric interview was conducted on both, cases and controls, and revealed that $46 \%$ of the cases of GERD met the diagnosis of depression and 31\% met the diagnosis of anxiety disorder, while among the controls the prevalence was $19 \%$ and $11 \%$ respectively. The difference in the prevalence rates of both groups was statistically highly significant with a p-value for both MINI-D as well as for MINIA. A study from China [22] used Zung Self-Rating scales for anxiety (ZSAS) and depression (ZSDS) along with SF-36 (Short Form Survey) on 279 patients of GERD and 100 controls to assess psychological morbidity and quality of life. Both anxiety and depression were found to be significantly higher in the patient group. And within the patient group, patients diagnosed with non-erosive reflux disease (NERD) showed significantly higher scores than patients having Reflux Oesophagitis. Similar findings were observed for ZSDS scores.

This could mean either that patients with NERD might have higher GERD symptom perception owing to their anxious/depressed status or that patients with RE might be relatively less sensitive to pain owing to mucosal changes. Literature on robust physiological studies needs to be explored to understand this difference, but good evidence is available to psychosocial stress and acid reflux, which may partially explain higher prevalence of depression/anxiety in these patients.

A study of 6,834 Korean subjects who underwent regular medical check-up (including upper GI endoscopy) found that $13.2 \%$ were in the high-stress group, and reflux oesophagitis was found in $6.0 \%$. After adjustment for confounders, reflux oesophagitis was significantly associated with high stress [23].

\section{GERD and Severity of Depression}

In this study, the severity of the depression and/or anxiety disorder was measured among the ones who screened positive in MINI interview. Hamilton rating scales for depression and anxiety were applied for this purpose. Among the cases 15 out of 46 subjects had scores indicating 'very severe' depression and 27 fell in the brackets of either 'moderate' or 'severe' illness. By contrast, only 7 subjects among the controls had 'very severe' depression. Similarly, 12 out of a total of 31 GERD cases who had anxiety had scores indicating 'severe' symptoms, while only 3 subjects among the control group fell in this severity group.

\section{CONCLUSION}

In summary, among the 100 GERD cases 56 were found to have psychiatric morbidity in form of either anxiety or depression. Demographic characteristics of the GERD patients were compared with regard to presence or absence of psychiatric morbidity. The numerical differences in different demographic indices 
like age, sex, marital status, education, place of residence, religion or occupation did not show statistical significance. Tobacco and/or alcohol use too did not seem to significantly affect the prevalence of depression or anxiety among the patients of GERD.

\section{REFERENCES}

1. Lee KJ, Kwon HC, Cheong JY, Cho SW. Demographic, clinical, and psychological characteristics of the heartburn groups classified using the Rome III criteria and factors associated with the responsiveness to proton pump inhibitors in the gastroesophageal reflux disease group. Digestion. 2009;79(3):131-6.

2. Dent J, Vakil N, Jones R, Bytzer P, Schöning U, Halling K, Junghard O, Lind T. Accuracy of the diagnosis of GORD by questionnaire, physicians and a trial of proton pump inhibitor treatment: the Diamond Study. Gut. 2010;59(6):714-21.

3. Sharma PK, Ahuja V, Madan K, Gupta S, Raizada A, Sharma MP. Prevalence, severity, and risk factors of symptomatic gastroesophageal reflux disease among employees of a large hospital in northern India. Indian J Gastroenterol 2011;30(3):128-34.

4. Avidan B, Sonnenberg A, Giblovich H, Sontag SJ. Reflux symptoms are associated with psychiatric disease. Aliment Pharmacol Therapeut 2001;15(12):1907-12.

5. Martin-Merino E, Ruigomez A, Garcia Rodriguez LA, Wallander MA, Johansson S. Depression and treatment with antidepressants are associated with the development of gastro- oesophageal reflux disease. Aliment Pharmacol Therapeut 2010;31(10):1132-40.

6. Hartono JL, Mahadeva S, Goh KL. Anxiety and depression in various functional gastrointestinal disorders: do differences exist? J Digest Dis 2012;13(5):252-7.

7. Stanghellini V. Relationship between upper gastrointestinal symptoms and lifestyle, psychosocial factors and comorbidity in the general population: results from the Domestic/International Gastroenterology Surveillance Study (DIGEST). Scand J Gastroenterol 1999;231:29-37.

8. Núñez-Rodríguez MH, Sivelo AM. Psychological factors in gastroesophageal reflux disease measured by scl90-R questionnaire. Digest Dis Sci 2008;53(12):3071-5.

9. Velanovich V, Karmy-Jones R. Psychiatric disorders affect outcomes of antireflux operations for gastroesophageal reflux disease. Surg Endoscopy 2001;15(2):171-5.

10. Mykletun A, Jacka F, Williams L, Pasco J, Henry M, Nicholson GC, Kotowicz MA, Berk M. Prevalence of mood and anxiety disorder in self reported irritable bowel syndrome (IBS). An epidemiological population based study of women. BMC gastroenterology. 2010 Dec;10(1):88.

11. Lee ES, Kim N, Lee SH, Park YS, Kim JW, Jeong SH, Lee DH, Jung HC, Song IS. Comparison of risk factors and clinical responses to proton pump inhibitors in patients with erosive oesophagitis and non- erosive reflux disease. Aliment Pharmacol Therapeut 2009;30(2):154-64.

12. Akiyama T, Inamori M, Iida H, Mawatari H, Endo H, Hosono K, Yoneda K, Fujita K, Yoneda M, Takahashi $\mathrm{H}$, Goto A. Alcohol consumption is associated with an increased risk of erosive esophagitis and Barrett's epithelium in Japanese men. BMC Gastroenterol 2008;8(1):58.

13. Ruigómez A, Rodríguez LA, Wallander MA, Johansson S, Jones R. Chest pain in general practice: incidence, comorbidity and mortality. Fam Pract 2006;23(2):167-74.

14. Whiteman DC, Sadeghi S, Pandeya N, Smithers BM, Gotley DC, Bain CJ, Webb PM, Green AC. Combined effects of obesity, acid reflux and smoking on the risk of adenocarcinomas of the oesophagus. Gut 2007;11(1):160-5.

15. Kahrilas PJ, Gupta RR. Mechanisms of acid reflux associated with cigarette smoking. Gut 1990;31(1):4-10.

16. Kaltenbach T, Crockett $\mathrm{S}$, Gerson LB. Are lifestyle measures effective in patients with gastroesophageal reflux disease?: an evidence-based approach. Arch Intern Med 2006;166(9):965-71.

17. Lee SP, Sung IK, Kim JH, Lee SY, Park HS, Shim CS. The effect of emotional stress and depression on the prevalence of digestive diseases. J Gastroenterol Motility 2015;21(2):273-8.

18. Singh M, Lee J, Gupta N, Gaddam S, Smith BK, Wani SB, Sullivan DK, Rastogi A, Bansal A, Donnelly JE, Sharma P. Weight loss can lead to resolution of gastroesophageal reflux disease symptoms: a prospective intervention trial. Obesity 2013;21(2):284-90.

19. El-Serag HB, Graham DY, Satia JA, Rabeneck L. Obesity is an independent risk factor for GERD symptoms and erosive esophagitis. Am J Gastroenterol 2005;100(6):1243-9.

20. Richard A, Rohrmann S, Lohse T, Eichholzer M. Is body weight dissatisfaction a predictor of depression independent of body mass index, sex and age? Results of a cross-sectional study. BMC Pub Health 2016;16(1):863. 
21. Lin WS, Hu LY, Liu CJ, Hsu CC, Shen CC, Wang YP, Hu YW, Tsai CF, Yeh CM, Chen PM, Su TP. Gastroesophageal reflux disease and risk for bipolar disorder: a nationwide population-based study. PloS One 2014;9(9):e107694.

22. Yang XJ, Jiang HM, Hou XH, Song J. Anxiety and depression in patients with gastroesophageal reflux disease and their effect on quality of life. World J Gastroenterol 2015;21(14):4302-8.

Acknowledgements - Nil

Conflict of Interest - Nil

Funding - Nil 